\title{
Germination capacity of five polar Caryophyllaceae and Poaceae species under different temperature conditions
}

\author{
Wioleta Kellmann-Sopyła ${ }^{1}$ Irena Giełwanowska ${ }^{1,2}$
}

Received: 18 November 2014/Revised: 31 May 2015/Accepted: 16 June 2015/Published online: 8 July 2015

(C) The Author(s) 2015. This article is published with open access at Springerlink.com

\begin{abstract}
A compilation of the literature relating to the germination of five species of polar vascular plants, Cerastium alpinum, Colobanthus quitensis, Silene involucrata, Deschampsia antarctica and Pоа аппиа, indicates that optimal temperature conditions for seed germination have never been identified for some of them, and the results reported for the remaining species are largely inconclusive. Our results and published findings suggest that significant differences in the germinability of the analysed five species and their species-specific germination responses to temperature and cold stratification could result from variations in their physiological dormancy levels. It is important that seed physiological development at time of collection, seed storing time and conditions are as equal as possible when comparing results from different studies. Our study revealed differences in the maximum germination percentages of those species, which ranged from very low $(C$. alpinum, $10 \%$ ) to very high (S. involucrata, $99 \%)$. Silene involucrata, $C$. quitensis and D. antarctica have fast-germinating seeds, whereas $P$. апnиа is a long germinating species. Within the range of four tested temperatures (12, $20,20 / 7$ and $30 / 20{ }^{\circ} \mathrm{C}$ ), the lowest germination percentage
\end{abstract}

Electronic supplementary material The online version of this article (doi:10.1007/s00300-015-1740-x) contains supplementary material, which is available to authorized users.

Wioleta Kellmann-Sopyła

wioleta.kellmann@uwm.edu.pl

1 Department of Plant Physiology, Genetics and Biotechnology, University of Warmia and Mazury in Olsztyn, Oczapowskiego 1A, 10-719 Olsztyn, Poland

2 Department of Antarctic Biology and Polish Antarctic Station "H. Arctowski", Institute of Biochemistry and Biophysics PAS, Ustrzycka 10/12, 02-141 Warsaw, Poland of $S$. involucrata seeds was observed at fluctuating temperature of $30 / 20{ }^{\circ} \mathrm{C}$ and $C$. quitensis seeds at $12{ }^{\circ} \mathrm{C}$, the highest germination percentage of $C$. quitensis seeds was reported at fluctuating temperature of $20 / 7{ }^{\circ} \mathrm{C}$ and $P$. апnиa seeds at $12{ }^{\circ} \mathrm{C}$, whereas the germination percentage of $D$. antarctica was not affected by temperature. A two-month cold stratification period stimulated germination in $C$. quitensis and D. antarctica, but it did not affect the germination of $C$. alpinum.

Keywords Antarctic $\cdot$ Arctic $\cdot$ Seed germination . Stratification - Temperature

\section{Introduction}

Plants are particularly sensitive to cold stress during the reproductive phase of their life cycle (Zinn et al. 2010), and it has been long believed that clonal growth and vegetative reproduction, which are more effective in unstable environments characterized by high levels of abiotic stress, play important roles in species growing in cold regions of the globe, including polar regions and high mountain ranges (Billings and Mooney 1968; Bliss 1971; Callaghan and Emanuelsson 1985; Jónsdittór et al. 1996). This conviction was supported by numerous observations indicating, that polar vascular plants produce very few seeds that are often nonviable (Sørensen 1941; Bliss 1962; Billings and Mooney 1968; Corner 1971; Edwards 1974; Bell and Bliss 1980). The results of recent research into the reproduction of polar plants do not confirm earlier findings. According to Brochmann and Steen (1999), the majority of 161 species of the Svalbard flora have mixed reproductive systems, where 97 species are mainly sexual and 36 are mainly clonal. Klimešová et al. (2012) demonstrated that polar 
vascular plants have less varied vegetative reproduction organs than Central European plants, and the proportions of clonal plants in the Arctic flora are comparable to those estimated in Central Europe. Recent research showed that the germination percentages of seeds produced by polar vascular plants are much higher than previously believed (Lewis-Smith 1994; Müller et al. 2011; Alsos et al. 2013). Our knowledge about the germinability of various species of polar vascular plants is being steadily expanded, but relatively little is known about their germination ecology, in particular optimal conditions for germination.

Temperature is undoubtedly one of the most important exogenous factors that regulate seed germination (Baskin and Baskin 2001). It can significantly influence the breaking and induction of dormancy as well as the capacity and rate of germination of non-dormant seeds (Bouwmeester and Karssen 1992; Brändel and Jensen 2005). Temperature and water availability are the major environmental factors that inhibit the survival of organisms in polar regions (Billings 1987; Block et al. 2009). Apart from low temperatures, temperature fluctuations that occur within a short period of time also considerably limit vegetation both in the Arctic and Antarctic (Bliss 1962; Alberdi et al. 2002; Peck et al. 2006; Convey 2012). Easy access of solar radiation and wind to soil surface, rocks and the above-ground parts of plants, microtopographic variation and snow cover can considerably modify temperature and water availability in habitats (Billings and Mooney 1968; Beyer et al. 2000; Alberdi et al. 2002; Parnikoza et al. 2011). Strong interactions between environmental factors and their variability contribute to high fluctuations in temperature, which can reach $20-30{ }^{\circ} \mathrm{C}$ within hours or minutes (Convey 2012). In view of their temperature and water availability, polar regions are among the world's most unstable environments (Block et al. 2009).

The aim of this study was to determine the effect of stratification and germination temperature on germination percentage and germination time in Cerastium alpinum, Colobanthus quitensis, Silene involucrata, Deschampsia antarctica and Роа аппиа. Moreover, our findings and other authors' results were used to build a comprehensive knowledge base relating to the influence of temperature on seed germination in the analysed species.

\section{Materials and methods}

\section{Plant material}

The study analysed the seeds of five herbaceous species of polar vascular plants. Two of them, C. alpinum L. and $S$. involucrata (Cham. and Schltdl.) Bocquet (Caryophyllaceae), are native to the Arctic region. The remaining three species, C. quitensis (Kunth) Bartl. (Caryophyllaceae), D. antarctica Desv. and P. апnиa L. (Poaceae), grow in the Antarctic, where C. quitensis and D. antarctica are native species, and $P$. аnnиa is an alien species that was introduced to the Antarctic several decades ago (Lewis Smith 1996; Olech 1996).

\section{Seed collection and storage}

The capsules and seeds of $C$. alpinum, $C$. quitensis and $S$. involucrata and the inflorescences and caryopses (referred to as seeds in this study) of D. antarctica and P. annua were collected during polar expeditions to King George Island (South Shetland Islands, Antarctic) and Spitsbergen (Svalbard, Arctic) in 2011-2012 (Table 1). Plant material was transported to laboratories in the Arctic and Antarctic, dried for several days at room temperature and transported to Olsztyn, Poland $\left(53^{\circ} 47^{\prime} \mathrm{N}, 20^{\circ} 30^{\prime} \mathrm{E}\right)$, where seeds were released from capsules and inflorescences. During transport and before germination tests, seeds were stored in paper envelopes, in darkness, at $4{ }^{\circ} \mathrm{C}$.

\section{Germination percentage and germination time}

Germination tests were performed 8 months after seed harvest. Seeds for the germination test were placed on petri dishes lined with filter paper and saturated with distilled water. Lemmas and paleas were not removed from grass seeds. Every tested variant was sown in four replications of 25 or 50 seeds each subject to availability (Table 1).

The germination tests were performed in a growth chambers at two fluctuating temperatures of $20 / 7{ }^{\circ} \mathrm{C}$ $(16 / 8 \mathrm{~h})$ and $30 / 20{ }^{\circ} \mathrm{C}(16 / 8 \mathrm{~h})$ and two constant temperatures of 12 and $20^{\circ} \mathrm{C}$. The $16-/ 8$-h photoperiod was identical for all temperatures. Germinated seeds were counted and removed daily over a period of 30 days. Water was regularly replenished in petri dishes. Seeds were regarded as germinated upon the emergence of the radicle. Germination tests lasted 30 days.

The seeds of species characterized by a very low germination response to all or most tested temperatures, from the treatment incubated at a constant temperature of $12{ }^{\circ} \mathrm{C}$, were left on petri dishes in darkness for 2 months at $4{ }^{\circ} \mathrm{C}$ (C. alpinum, C. quitensis and D. antarctica). Moisture levels were kept constant throughout the entire incubation period. After 2 months of incubation at $4{ }^{\circ} \mathrm{C}$, seeds were subjected to a second germination test at $20^{\circ} \mathrm{C}$ for 30 days with a 16-/8-h photoperiod. This treatment was labelled as $12 / 4 / 20{ }^{\circ} \mathrm{C}$. After germination, the viability of ungerminated seeds was determined in a tetrazolium test according to AOSA and SCST (2010). The tetrazolium test was performed on the seeds of species whose maximum 
Table 1 Collection sites, dates and total number $(\mathrm{N})$ of seeds used in germination experiments

\begin{tabular}{|c|c|c|c|}
\hline Species & Collection site & Coll. date & $\mathrm{N}$ \\
\hline \multicolumn{4}{|l|}{ Caryophyllaceae } \\
\hline Cerastium alpinum & Nicolaus Copernicus University Polar Station, Kaffiøyra $\left(78^{\circ} 41^{\prime} \mathrm{N}, 11^{\circ} 51^{\prime} \mathrm{E}\right.$; Spitsbergen) & 03 August 2012 & 400 \\
\hline Colobanthus quitensis & Lions Rump, King George Bay $\left(62^{\circ} 08^{\prime} \mathrm{S}, 58^{\circ} 08^{\prime} \mathrm{W}\right.$; King George Island) & 03 March 2012 & 800 \\
\hline Silene involucrata & Stanisław Siedlecki Polish Polar Station in Hornsund $\left(77^{\circ} 00^{\prime} \mathrm{N}, 15^{\circ} 33^{\prime} \mathrm{E}\right.$; Spitsbergen $)$ & 10 August 2012 & 400 \\
\hline \multicolumn{4}{|l|}{ Poaceae } \\
\hline $\begin{array}{l}\text { Deschampsia } \\
\text { antarctica }\end{array}$ & Lions Rump, King George Bay $\left(62^{\circ} 08^{\prime} \mathrm{S}, 58^{\circ} 08^{\prime} \mathrm{W}\right.$; King George Island) & $\begin{array}{l}15 \text { February } \\
2012\end{array}$ & 800 \\
\hline Роа аппиа & $\begin{array}{l}\text { Henryk Arctowski Polish Polar Station, Admiralty Bay }\left(62^{\circ} 09^{\prime} \mathrm{S}, 58^{\circ} 28^{\prime} \mathrm{W} \text {; King George }\right. \\
\text { Island) }\end{array}$ & 25 March 2012 & 800 \\
\hline
\end{tabular}

germination percentages were less than $95 \%$ (C. alpinum, C. quitensis, D. antarctica and P. annua).

Germination results were used to determine the final percentage of germinated seeds (referred to as germination percentage in this study) and calculate mean germination time (MGT) (Ranal and De Santana 2006) with the use of the following formula: MGT $=\frac{\sum n_{t} * t}{\sum n_{t}}$, where $n_{t}$ : number of seeds newly germinated on day $t, t$ : number of days from the beginning of the germination test to the observation on day $t(1,2, \ldots, 30)$. The germination percentage and viability of seeds were calculated relative to the total number of sown seeds in a given repetition.

\section{Statistical analyses}

The significance of differences in germination percentages at different temperatures was determined by the KruskalWallis test and the Mann-Whitney $U$ post-test for multiple comparisons. The above nonparametric statistics were used, since our germination data were not normally distributed. The significance of differences in mean germination time between the analysed temperature variants was determined by Kaplan-Meier survival curve and the logrank post-test. Calculations were performed separately for each species at a significance level of $\alpha=0.05$. The results were processed statistically in the Statistica v. 10 application (StatSoft Polska).

\section{Comparison with previous studies}

We compiled data from research studies into the germination responses of $C$. alpinum, $C$. quitensis, $S$. involucrata, D. antarctica and $P$. апnиa seeds under controlled laboratory conditions to compare our results with the findings of other authors (Holtom and Greene 1967; Corner 1971; Edwards 1974; Frenot and Gloaguen 1994; Day et al. 1999; Ruhland and Day 2001; Giełwanowska et al. 2005;
Müller et al. 2011; Alsos et al. 2013; Wódkiewicz et al. 2013). The geographic range of all five species is not confined to the polar regions. The information concerning C. alpinum and $S$. involucrata was narrowed down to the germination of seeds collected from plants growing in the Arctic, and the findings relating to $C$. quitensis, $D$. antarctica and $P$. annua were restricted to seeds harvested in the Antarctic and Subantarctic. This limitation was introduced to ensure that only the germination percentages of seeds that developed in the same climate zone, i.e. circumpolar zone, were compared in this study. Germination results were compared based on temperature and photoperiod during germination, place of seed harvest and seed storage conditions before the germination test.

\section{Results}

\section{Germination percentages at different temperatures and after cold stratification}

The seeds of the analysed polar plants of the families Caryophyllaceae and Poaceae were characterized by varied maximum germination percentages, which ranged from very low (C. alpinum, $10 \%$ ), through low (D. antarctica, $30.5 \%$, P. annua, $34 \%$ ), high (C. quitensis, $79.5 \%)$, to very high (S. involucrata, $99 \%$ ) (Fig. 1). The germination responses of the studied species to temperature and stratification were species specific. The most significant impact of temperature was observed in $C$. quitensis whose germination percentage at fluctuating temperature of $20 / 7{ }^{\circ} \mathrm{C}$ reached $70 \%$, and was at least $59 \%$ lower (max. $11 \%$ ) in the three remaining temperature variants (12, 20 and $30 / 20{ }^{\circ} \mathrm{C}$, Table 2). The percentage of $D$. antarctica seeds that germinated in all four temperature variants was minimal (1-3\%), and hence, temperature had no effect on their germination percentages (Table 2). The seeds of the Arctic species of $S$. involucrata were characterized by the 


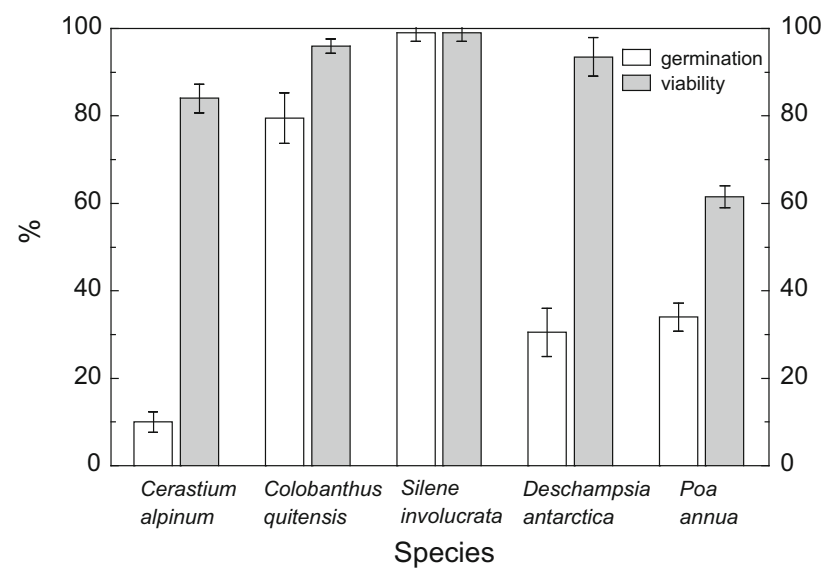

Fig. 1 Maximum germination percentages and viability of seeds \pm SD of the five polar representatives of Caryophyllaceae and Poaceae family

lowest germination percentage at fluctuating temperature of $30 / 20{ }^{\circ} \mathrm{C}$, and no significant differences in their germination percentages were reported at the remaining three temperatures $\left(20 / 7,12\right.$ and $20^{\circ} \mathrm{C}$, Table 2). At a constant temperature of $12{ }^{\circ} \mathrm{C}$, the seeds of $C$. quitensis germinated least abundantly, whereas the reverse was reported for $P$. апnиa whose germination percentage reached $34 \%$ at $12{ }^{\circ} \mathrm{C}$ and was at least 1.5 -fold higher than in the remaining temperature variants (Table 2).

The two-month cold stratification period (darkness, $4{ }^{\circ} \mathrm{C}$ ) significantly stimulated germination percentages of C. quitensis and D. antarctica seeds (Table 2). The germination percentage of stratified seeds of $C$. quitensis at $20{ }^{\circ} \mathrm{C}(79.5 \%)$ was similar to the germination percentage of unstratified seeds at fluctuating temperatures of $20 / 7{ }^{\circ} \mathrm{C}$ (70 \%). In comparison with C. quitensis, cold stratification did not induce a similarly stimulating effect on $D$. antarctica where only $30 \%$ of seeds germinated. A significant improvement in the germination percentage of $C$. alpinum seeds was not observed (Table 2).

Based on the number of germinated seeds and the results of the tetrazolium test, seed viability was estimated at $60 \%$ in $P$. annua, more than $80 \%$ in C. alpinum and more than $90 \%$ in the three remaining species (Fig. 1).

\section{Germination time at different temperatures and after cold stratification}

Germination time could not be determined in C. alpinum due to very weak seed germination (Fig. 1; Table 2; Online Resource 1a). In the remaining species, short mean germination time was reported in the seeds of S. involucrata (4.0-6.1 days) and in the stratified seeds of $C$. quitensis (6.5 days) and $D$. antarctica (3.7 days), most of which germinated during the first 7 days of the test (Online Resource 1b-d). P. апnиа seeds were characterized by much longer mean germination time (16.3-19.8 days) which covered nearly the entire period of the test (Table 3; Online Resource 1e).

The influence of temperature on germination time was determined only in S. involucrata, $C$. quitensis and $P$. аппиа, because in only those three species, germination percentages exceeded $10 \%$ in response to at least two temperatures (Table 2). In all three species, temperature influenced seed germination time to a certain degree. The seeds of S. involucrata germinated faster at $20^{\circ} \mathrm{C}$, and their germination time was 1.5-2 days shorter than in the three remaining temperature variants (Table 3 ). The germination percentage of unstratified seeds of $C$. quitensis was higher at fluctuating temperatures of $20 / 7{ }^{\circ} \mathrm{C}$ than at $20{ }^{\circ} \mathrm{C}$ (Table 2), but their germination time was reduced by 2 days at the latter temperature (Table 3). P. апnиа seeds germinated most profusely at a constant temperature of $12{ }^{\circ} \mathrm{C}$ (Table 2), but their germination time at that temperature was 2-3 days longer than in the remaining temperature variants (Table 3 ).

\section{Comparison with previous studies}

Our findings and the results of other studies into the germinability of $C$. alpinum, S. involucrata, C. quitensis, D. antarctica and $P$. апnиa seeds are presented in Table 2 . We were unable to find any published data concerning the germination percentages of $C$. alpinum. The seeds of $S$. involucrata from Svalbard have been germinated at only two similar temperatures of 18 (Müller et al. 2011) and $20{ }^{\circ} \mathrm{C}$ (Alsos et al. 2013). The above findings and our results indicate that $S$. involucrata seeds are characterized by high or very high germination percentages. In the study by Alsos et al. (2013), the germination percentage of $S$. involucrata seeds was determined at nearly $70 \%$, whereas in the work of Müller et al. (2011) and in our study, conducted at two constant temperatures $\left(12\right.$ and $\left.20^{\circ} \mathrm{C}\right)$ and at fluctuating temperature $\left(20 / 7{ }^{\circ} \mathrm{C}\right)$, the germination percentage of S. involucrata approximated $100 \%$.

To date, the germination percentages of $P$. аппиа seeds produced in the Antarctic or Subantarctic have been identified at only one fluctuating temperature of $20 / 4{ }^{\circ} \mathrm{C}$ (Wódkiewicz et al. 2013) and at three constant temperatures of 5, 10 and $20{ }^{\circ} \mathrm{C}$ (Frenot and Gloaguen 1994). Our results and the findings of Frenot and Gloaguen (1994) indicate that $P$. апnиа seeds are able to germinate within a wide range of temperatures, but the optimal temperature for the germination of both Antarctic and Subantarctic seeds is a constant temperature of 10 or $12{ }^{\circ} \mathrm{C}$.

In the evaluated group of species, the seeds of $C$. quitensis and $D$. antarctica have been germinated within the widest temperature range. The above species have been germinated at different constant temperatures which ranged 


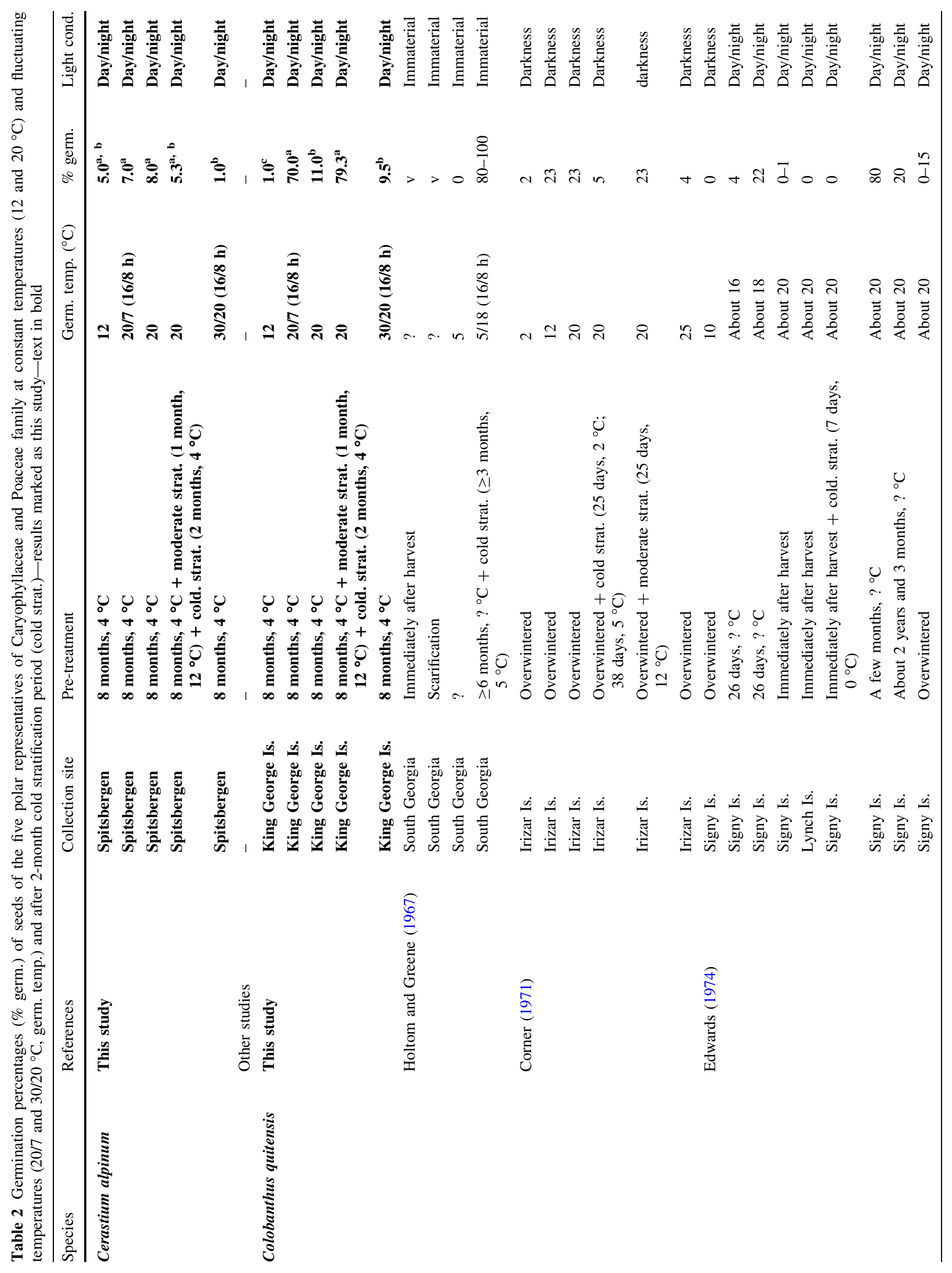




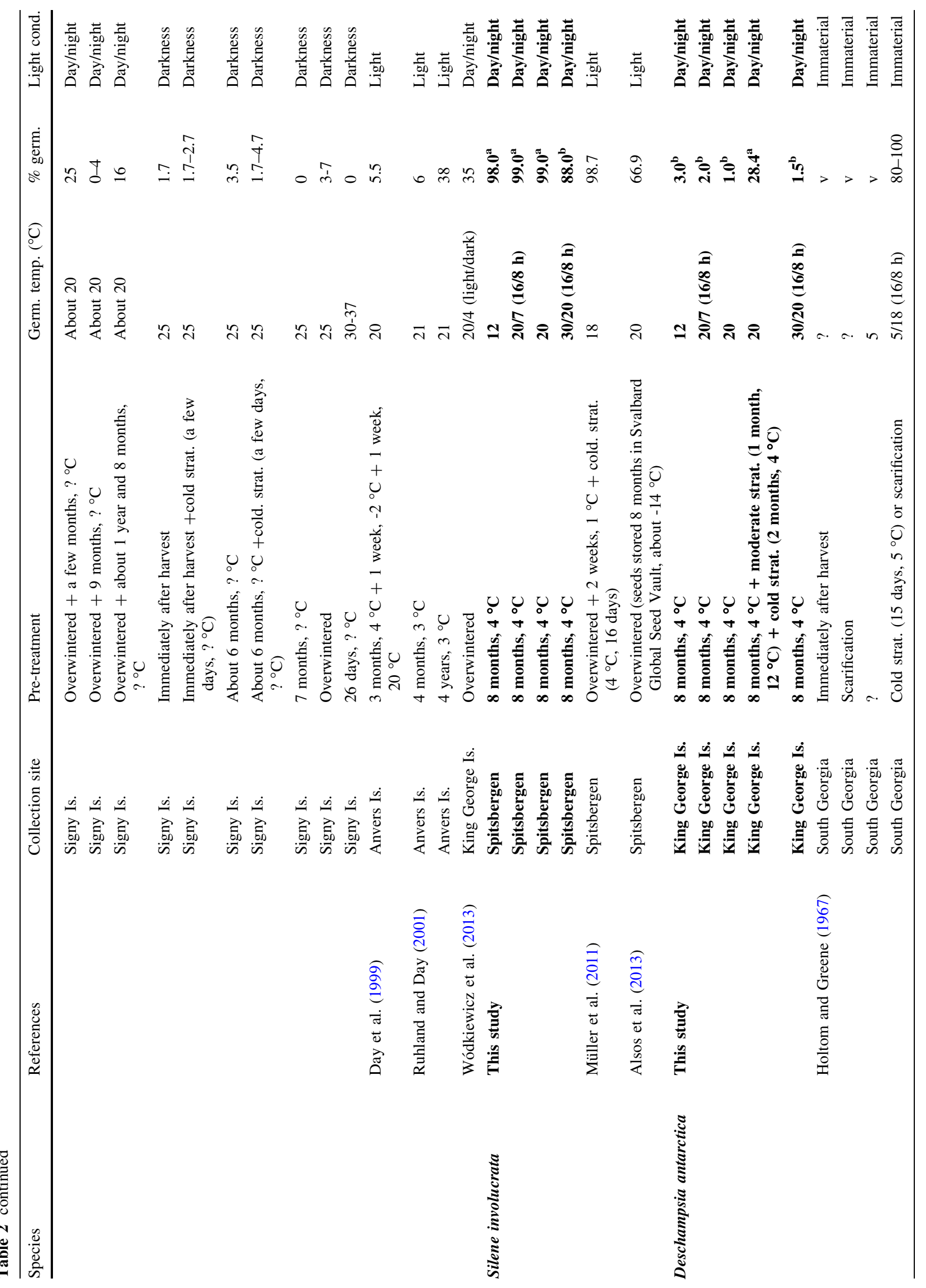




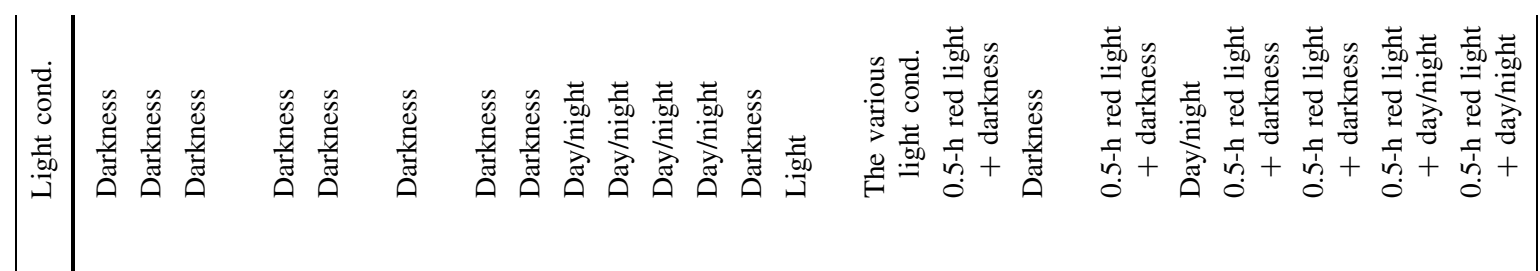

$$
\begin{aligned}
& \text { oma }
\end{aligned}
$$

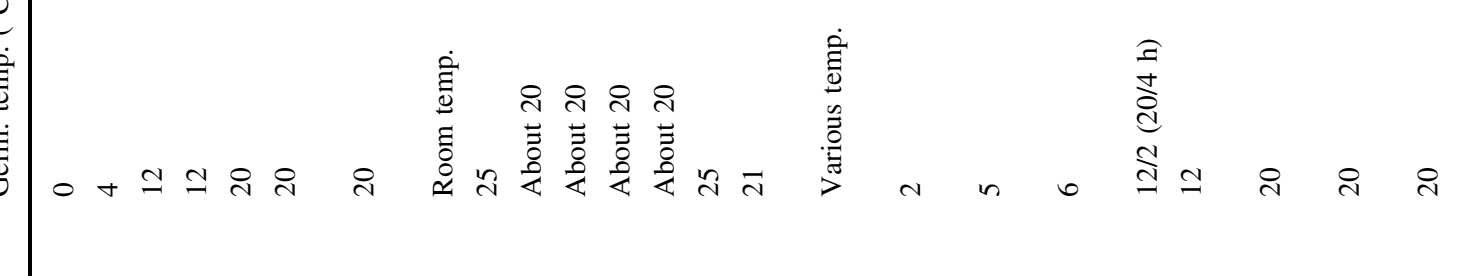

$$
\begin{aligned}
& \begin{array}{llll}
0 & 0 \\
0 & 0 & 0 & 0
\end{array}
\end{aligned}
$$

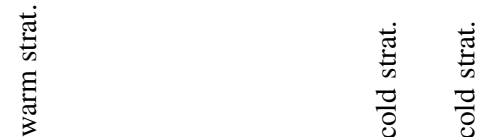

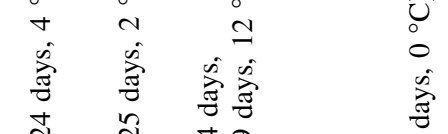

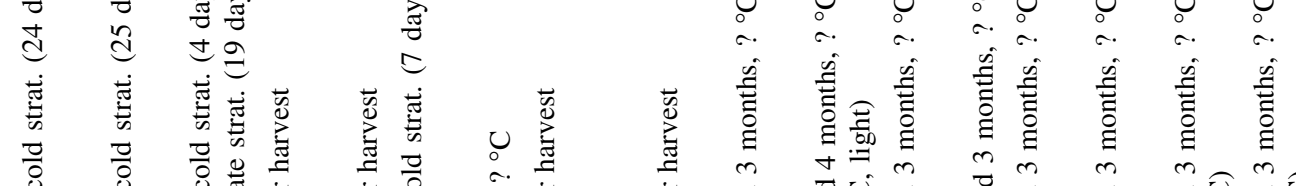

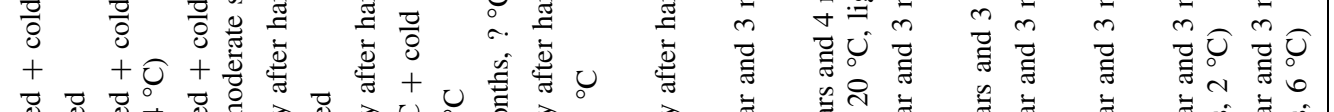

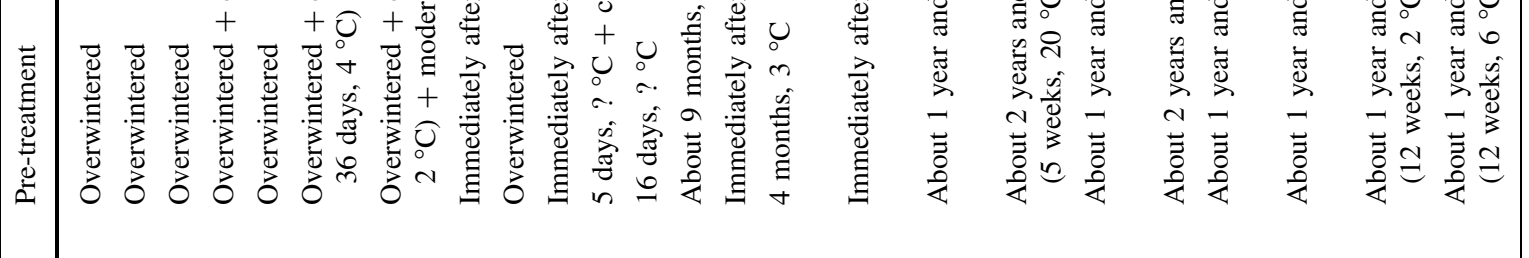

$$
\begin{aligned}
& \text { 莺 }
\end{aligned}
$$

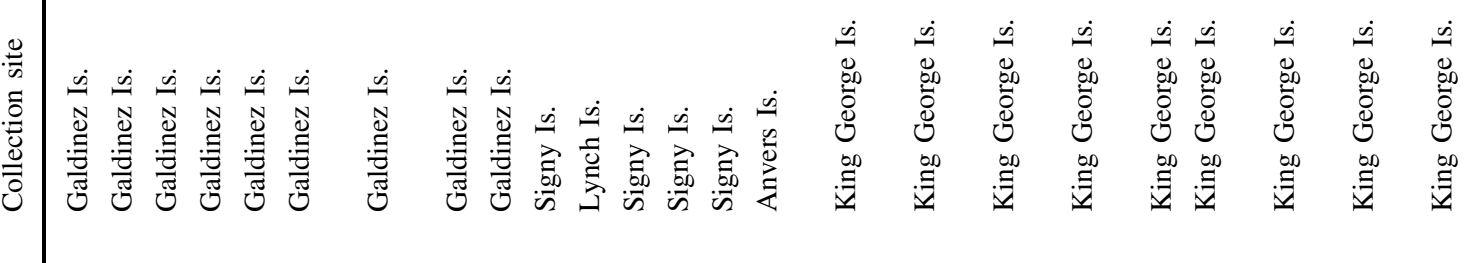

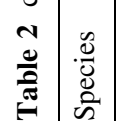

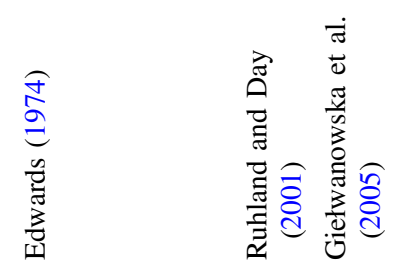




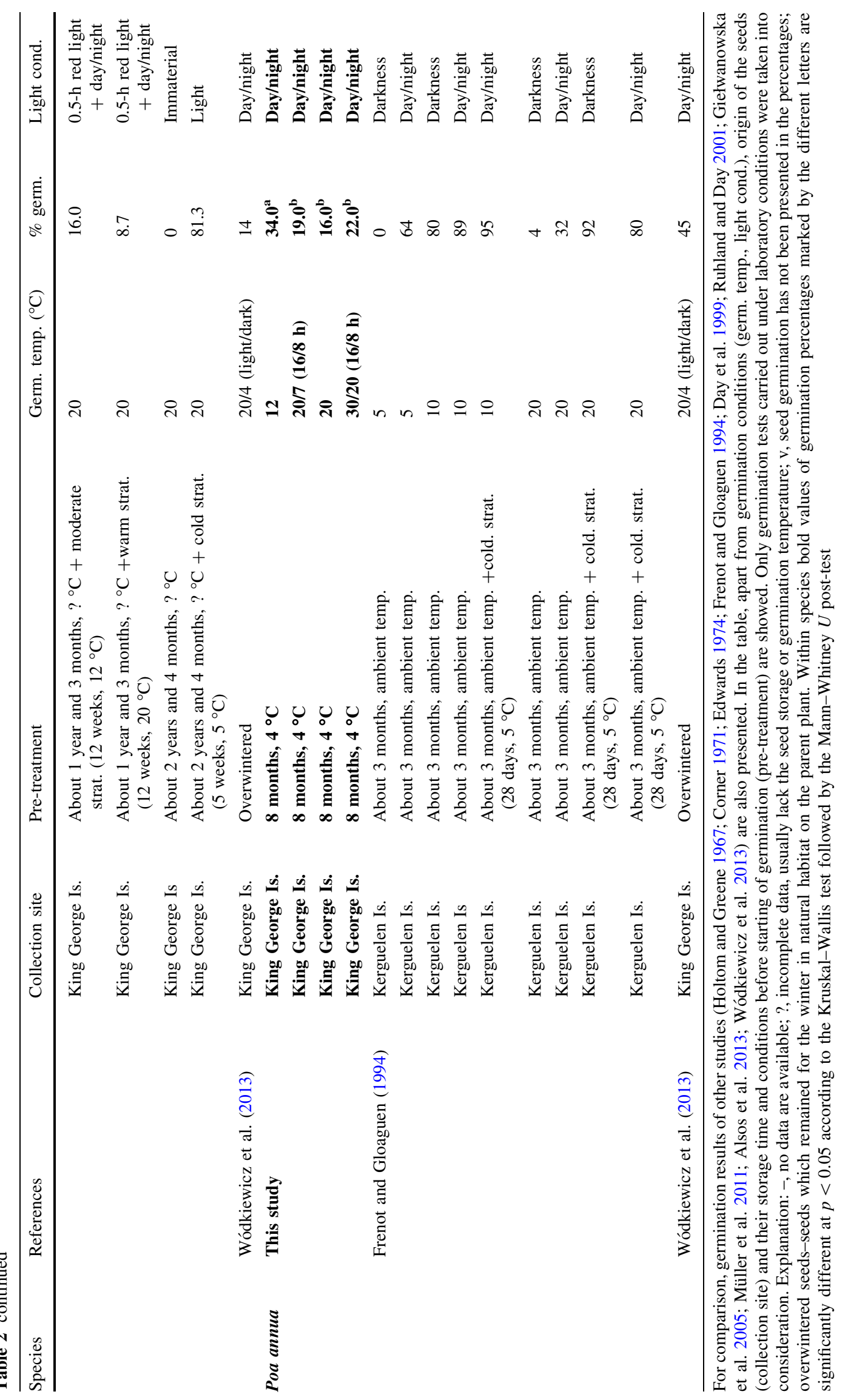


Table 3 Mean germination time of seeds of the five polar representatives of Caryophyllaceae and Poaceae family at constant $\left(12\right.$ and $\left.20{ }^{\circ} \mathrm{C}\right)$, and fluctuating temperatures $\left(20 / 7\right.$ and $\left.30 / 20{ }^{\circ} \mathrm{C}\right)$ and after two-month cold stratification at $4{ }^{\circ} \mathrm{C}\left(12 / 4 / 20{ }^{\circ} \mathrm{C}\right)$

\begin{tabular}{|c|c|c|c|c|c|}
\hline \multirow[t]{2}{*}{ Species } & \multicolumn{5}{|c|}{ Mean germination time (days) } \\
\hline & $20 / 7{ }^{\circ} \mathrm{C}$ & $12{ }^{\circ} \mathrm{C}$ & $20^{\circ} \mathrm{C}$ & $30 / 20{ }^{\circ} \mathrm{C}$ & $12 / 4 / 20{ }^{\circ} \mathrm{C}$ \\
\hline Cerastium alpinum & $*$ & $*$ & $*$ & $*$ & $*$ \\
\hline Colobanthus quitensis & $10.8^{\mathrm{a}}$ & $*$ & $8.3^{\mathrm{b}}$ & $*$ & $6.5^{\mathrm{c}}$ \\
\hline Silene involucrata & $5.6^{\mathrm{b}}$ & $6.1^{\mathrm{a}}$ & $4.0^{\mathrm{c}}$ & $5.7^{\mathrm{a}, \mathrm{b}}$ & - \\
\hline Deschampsia antarctica & $*$ & $*$ & $*$ & $*$ & 3.7 \\
\hline Роа аппиа & $17.7^{\mathrm{b}}$ & $19.8^{\mathrm{a}}$ & $16.3^{\mathrm{b}}$ & $17.4^{\mathrm{b}}$ & - \\
\hline
\end{tabular}

*, too low germination percentage of seeds $(\leq 10 \%$, see Table 2$)$ to calculate MGT; - , germination test was not conducted. Values within row marked by the different letters are significantly different at $p<0.05$ according to Kaplan-Meier survival curve and the log-rank post-test

from 2 to $37^{\circ} \mathrm{C}$ for $C$. quitensis, and from 0 to $25^{\circ} \mathrm{C}$ for $D$. antarctica (Holtom and Greene 1967; Corner 1971; Edwards 1974; Day et al. 1999; Ruhland and Day 2001; Giełwanowska et al. 2005). Significantly fewer germination tests have been conducted for the above species at alternating temperatures (Holtom and Greene 1967; Giełwanowska et al. 2005; Wódkiewicz et al. 2013).

The majority of germination tests carried out by Holtom and Greene (1967), Corner (1971), Edwards (1974), Day et al. (1999), Ruhland and Day (2001) and Giełwanowska et al. (2005), and the tests performed in our study indicate that $C$. quitensis and D. antarctica seeds germinate weakly or do not germinate at all at constant temperatures, whether low $\left(\leq 10^{\circ} \mathrm{C}\right)$, medium $\left(12-16^{\circ} \mathrm{C}\right)$ or high $\left(\geq 18^{\circ} \mathrm{C}\right)$. Less unequivocal results were reported in tests analysing the effects of fluctuating temperatures and cold stratification on the evaluated species. In our study, C. quitensis seeds germinated profusely at fluctuating temperature of $20 / 7{ }^{\circ} \mathrm{C}$ or after 2 months of cold stratification, whereas $D$. antarctica seeds were only somewhat stimulated for germination after 2 months of cold stratification. In a study by Holtom and Greene (1967), the germination of $C$. quitensis and $D$. antarctica seeds was visibly stimulated by fluctuating temperatures of $5 / 18{ }^{\circ} \mathrm{C}$ and cold stratification. According to Corner (1971), 2 months of cold stratification did not induce germination in $C$. quitensis, but significantly increased the germination percentage of $D$. antarctica seeds in excess of $70 \%$. Edwards (1974) observed that germination percentages of $C$. quitensis and D. antarctica seeds were not influenced by several days of cold stratification. Giełwanowska et al. (2005) observed that D. antarctica seeds can remain dormant for up to 2 years after harvest and can be released from dormancy by both cold and warm stratification.

\section{Discussion}

The optimal range of temperatures for seed germination generally corresponds to the thermal conditions characteristic of their region of origin (Baskin and Baskin 1988;
Probert 2000). Polar regions are characterized by a short and cold growing season (Savile 1972; Robinson et al. 2008), which could suggest that plant species native to the Arctic (C. alpinum and S. involucrata) and the Antarctic (C. quitensis and D. antarctica) should thrive at low temperatures. Mean summer temperatures range from 1.5 to $3.5^{\circ} \mathrm{C}$ on King George Island (Angiel et al. 2010; Kejna et al. 2013), and from 3 to $5{ }^{\circ} \mathrm{C}$ in western Spitsbergen (Førland et al. 2011). However, polar plants are exposed to temperatures that are more supportive for growth. Due to low and compact growth forms, Antarctic and Arctic phanerogams grow directly above the ground and rocks where temperature is several degrees or even more than $10^{\circ}$ higher than recorded by meteorological stations (Bliss 1962; Corner 1971; Edwards 1974; Chapin 1983). For this reason, we assumed that $12{ }^{\circ} \mathrm{C}$ could be the optimal temperature for the germination of $C$. alpinum, $S$. involucrata, C. quitensis and D. antarctica seeds. Yet in the tested temperature range $\left(12,20,20 / 7\right.$ and $\left.30 / 20{ }^{\circ} \mathrm{C}\right)$, germination percentages did not improve significantly at $12{ }^{\circ} \mathrm{C}$ in any of the above species. Constant temperatures are generally less favourable for germination than fluctuating temperatures, and selected species germinate only in response to alternating temperatures (Baskin and Baskin 2001). The above can be attributed to the fact that plants inhabiting higher latitudes are usually exposed to fluctuating temperatures. This is also observed in polar regions which are characterized by highly changeable weather conditions, in particular temperature (Bliss 1962; Block et al. 2009). Despite the above, in our experiment, significantly higher germination percentages at fluctuating temperatures, comprising alternating periods of lower $\left(7^{\circ} \mathrm{C} ; 8 \mathrm{~h}\right)$ and higher $\left(20^{\circ} \mathrm{C} ; 16 \mathrm{~h}\right)$ temperatures that imitated daily temperature cycles in the natural habitat, were observed only in $C$. quitensis.

In sites that are favourably situated, shielded from the wind and directly exposed to sunlight, ground surface temperatures in both the Arctic and Antarctic regions may be even several dozen Celsius degrees higher than ambient temperature. In the Arctic, ground surface temperature was 
determined at $50{ }^{\circ} \mathrm{C}$ on sunny days, and maximum temperature reached $68{ }^{\circ} \mathrm{C}$ (Gates 1980). In East Antarctic near the Molodezhnaya station, the highest recorded ground surface temperature was $42{ }^{\circ} \mathrm{C}$ (MacNamara 1973 in Campbell and Claridge 1987). Extremely high soil temperatures are noted very rarely, on cloudless and windless days, and over short periods of time, usually around noon. In most polar locations, very high temperatures or temperature fluctuations were reported mostly on rocks or gravel (Scherrer and Körner 2010). Temperature fluctuations and maximum temperatures are buffered by water in moist sites. Germination is only expected in the moist sites, but it is unlikely to succeed on rocks and gravel. Despite the above, germination tests in our study were conducted at a high temperature of $30 / 20{ }^{\circ} \mathrm{C}$ because according to Billings and Mooney (1968), the optimal temperature range for seed germination of Arctic species falls in the range of $20-30{ }^{\circ} \mathrm{C}$. In our study, no differences in the germination percentages of $S$. involucrata were observed at 12,20 or $20 / 7{ }^{\circ} \mathrm{C}$, but significantly lower germination percentage was noted at a high alternating temperature of $30 / 20{ }^{\circ} \mathrm{C}$. Baskin and Baskin (2001) have rightly observed that in many studies, the germination percentages of Arctic plants were tested at only one temperature. Therefore, the ensuing conclusion that seeds require high temperatures for germination may not be entirely correct. Bell and Bliss (1980) reported a lower range of optimal temperatures at $12-20{ }^{\circ} \mathrm{C}$ for the germination of Arctic species.

The fifth species analysed in this study was $P$. аппиа, a species native to Eurasia that has spread widely across the globe (Soreng 2007). In addition to Poa pratensis (Pertierra et al. 2013), it is the only alien vascular plant species to have colonized the Maritime Antarctic several decades ago (Lewis Smith 1996; Olech 1996; Molina-Montenegro et al. 2012). The high colonization capacity of $P$. апnиa can be attributed to its very high reproductive potential. During the growing season, an annual bluegrass produces several dozen to several hundred inflorescences containing thousands of maturing seeds (Warwick 1979). Those seeds can germinate within a wide range of temperatures, but the optimal temperature can differ between ecotypes (see Vargas and Turgeon 2004). In our study, the seeds of annual bluegrass also germinated at all four tested temperatures, but the highest percentage of germinated seeds was noted at $12{ }^{\circ} \mathrm{C}$. The optimal temperature for the germination of $P$. апnиа seeds harvested from a Subantarctic island was similar $\left(10{ }^{\circ} \mathrm{C}\right)$ in the study by Frenot and Gloaguen (1994). The common germination response of $P$. аппиа seeds from the Maritime Antarctic and Subantarctic could indicate those populations have adapted to the temperatures of polar regions. Significant morphological and physiological differences between ecotypes inhabiting different environments testify to considerable adaptive potential of P. аппиа (Ellis 1973; Lush 1989; Dionne et al. 2001).

Most vascular plant species native to Arctic tundra (McGraw and Vavrek 1989; Cooper et al. 2004) and two indigenous Antarctic phanerogams (McGraw and Day 1997; Ruhland and Day 2001) have large soil seed banks that comprise seeds at various phases of dormancy. For this reason, significant variations in the maximum germination percentages of $C$. alpinum, $S$. involucrata, $C$. quitensis and D. antarctica (10-99\%) and their species-specific germination responses to temperature and stratification could be attributed to their different levels of dormancy. The seeds of the analysed species were characterized by significant differences in germination percentages, but all of them were highly viable. The release from non-deep dormancy can be triggered by various physical factors. Such seeds often germinate within a very narrow range of temperatures or after several days or weeks of cold or warm stratification (Baskin and Baskin 2001). Seeds with intermediate or deep dormancy are unable to germinate at any temperature unless they are subjected to a relatively long period of cold stratification (Baskin and Baskin 2001). High germination percentage of $C$. quitensis seeds only in response to fluctuating temperature of $20 / 7{ }^{\circ} \mathrm{C}$ or after cold stratification at $4{ }^{\circ} \mathrm{C}$ could be indicative of non-deep physiological dormancy. Very low germination of non-stratified $D$. antarctica seeds and only partial improvement in their germination percentage after two-month cold stratification period point to intermediate or deep physiological dormancy. The results reported by Baskin and Baskin (2001) coming from studies of seeds from the Arctic tundra indicate that dormant seeds of Arctic plant species of the genera Cerastium and Silene are characterized by physiological dormancy. Those species are inclusive of $S$. involucrata (syn. Melandrium furcatum) which, in our study, was characterized by high germination percentages at all four temperatures without prior stratification. Our germination tests were conducted 8 months after harvest, and those seeds were probably released from dormancy during that period. Very low germination percentages of $C$. alpinum seeds, even after cold stratification, could indicate that this species has different dormancy breaking requirements. For example, Cerastium beeringianum, an Alpine species, has to go through an after-ripening period at room temperature to overcome dormancy (Bonde 1965).

The viability of $P$. апnиa seeds (approximately $60 \%$ ) was relatively low in comparison with the very high seed viability of the remaining Antarctic phanerogams (above $90 \%$ ), and those differences could be attributed to seed maturity at harvest. Although $P$. апnиa seeds were harvested at the end of austral summer (Table 1), a large part of seeds inside inflorescences had not reached full maturity. 
The above could have also contributed to the low germination percentages (max. $34 \%$ ) of $P$. аппиа seeds in our experiment. We were unable to determine with full certainty whether seed immaturity lowered their vigour or whether their low germination percentages resulted from dormancy. Other studies indicate that in the Antarctic, the size of the soil seed bank of $P$. апnиа (Wódkiewicz et al. 2013 , 2014) is comparable to that of $C$. quitensis and $D$. antarctica (McGraw and Day 1997; Ruhland and Day 2001). Moreover, P. апnиа seeds isolated from the soil bank in the Antarctic are viable, and their germinability exceeds $80 \%$ (Wódkiewicz et al. 2014).

Successful seed germination is determined not only by germination capacity, but also by germination rate which can be expressed by germination time (Ranal and De Santana 2006). Our study revealed that $S$. involucrata seeds and stratified seeds of $C$. quitensis and D. antarctica germinate within nearly 1 week, which indicates that those seeds are capable of germinating rapidly when dormancy is broken. In view of a very short growing season in polar regions, this strategy contributes to the establishment success of seedlings before the onset of winter.

To date, the majority of research into germination of polar vascular plants focused on their germination percentages, but very few studies analysed their germination rates (Frenot and Gloaguen 1994; Hagen 2002; Wódkiewicz et al. 2013). The germination time of two vascular plants native to the Antarctic, $C$. quitensis and D. antarctica, and the alien species $P$. апnиa, reported by Wódkiewicz et al. (2013) differs considerably from our findings and indicates that $P$. апnи $a$ can germinate as fast as or even faster than $C$. quitensis and $D$. antarctica. The above differences could result from variations in physiological state of seeds. Firstly, the compared seeds matured in different growing seasons. Secondly, Wódkiewicz et al. (2013) harvested seeds from previous year's inflorescences that had wintered on plants, whereas the seeds for our experiment were collected from current year's inflorescences. In our study, the incomplete maturity of $P$. апnиa seeds could have significantly prolonged their germination time. The differences in results could also be attributed to pre-germination treatments and different germination conditions. In our experiment, stratification and germination temperature influenced germination time of the analysed species.

\section{Conclusion}

The results of our study and other research investigating the germination percentages of five polar vascular plant species in a controlled environment revealed numerous discrepancies, which demonstrates that further work is needed to determine optimal germination conditions and dormancy mechanisms in the seeds of the evaluated species. There are hardly any published data relating to the germination requirements of two Arctic species, C. alpinum and $S$. involucrata. Published information about $P$. аппиа seeds formed in the Antarctic is also scarce. The latter species has been widely investigated as a cosmopolitan weed (e.g. Warwick 1979; Vargas and Turgeon 2004), but research into its reproductive ability in the Antarctic has been undertaken only in recent years (Wódkiewicz et al. 2013, 2014). Many studies analysing the germination capacity of indigenous Antarctic phanerogams contain incomplete data about their seed storage or germination conditions (e.g. Holtom and Greene 1967; Edwards 1974).

Our results and published findings suggest that the speciesspecific germination responses of the five analysed species to temperature and stratification can be attributed to differences in their levels of physiological dormancy. However, seed dormancy levels of those species are difficult to determine with full certainty. Seed dormancy status is influenced by environmental conditions during seed development, and in mature seeds, dormancy status continues to change in response to external factors (Finch-Savage and Leubner-Metzger 2006). The variations observed in the environmental conditions of polar regions across years (Callaghan et al. 1999; Kejna 1999; Ferron et al. 2004) suggest that seeds harvested in various growing seasons, in particular seeds collected from previous year's inflorescences, could differ in their dormancy levels and, consequently, their germination percentages at the same temperature. Varied storage conditions in a controlled environment can also significantly modify seed dormancy levels and contribute to different germination responses under exposure to the same temperature. The majority of studies conducted to date did not analyse the viability of ungerminated seeds of polar vascular plants, and therefore, lack of germination responsiveness could also be attributed to their low seed viability.

Acknowledgments This research was partly supported by the National Science Centre of the Republic of Poland Grant 2013/09/B/ NZ8/03293. We would like to thank reviewers for constructive advice, which has improved our paper.

Open Access This article is distributed under the terms of the Creative Commons Attribution 4.0 International License (http://creativecommons.org/licenses/by/4.0/), which permits unrestricted use, distribution, and reproduction in any medium, provided you give appropriate credit to the original author(s) and the source, provide a link to the Creative Commons license, and indicate if changes were made.

\section{References}

Alberdi M, Bravo LA, Gutierrez A, Gidekel M, Corcuera LJ (2002) Ecophysiology of Antarctic vascular plants. Physiol Plant 115:479-486 
Alsos IG, Müller E, Eidesen PB (2013) Germinating seeds or bulbils in 87 of 113 tested Arctic species indicate potential for ex situ seed bank storage. Polar Biol 36:819-830. doi:10.1007/s00300013-1307-7

Angiel PJ, Potocki M, Biszczuk-Jakubowska J (2010) Weather condition characteristics at the H. Arctowski Station (South Shetlands, Antarctica) for 2006, in comparison with multi-year research results. Misc Geogr 14:79-89

AOSA and SCST (2010) Tetrazolium testing handbook. Association of Official Seed Analysts and Society of Commercial Seed Technologists, Ithaca

Baskin CC, Baskin JM (1988) Germination ecophysiology of herbaceous plant species in a temperate region. Amer J Bot 75:286-305

Baskin CC, Baskin JM (2001) Seeds: ecology, biogeography and evolution of dormancy and germination. Academic Press, San Diego

Bell KL, Bliss LC (1980) Plant reproduction in a high arctic environment. Arct Alp Res 12:1-10

Beyer L, Bölter M, Seppelt RD (2000) Nutrient and thermal regime, microbial biomass and vegetation of Antarctic soils in the Windmill Islands region of east Antarctica (Wilkes Land). Arct Antarct Alp Res 32:30-39

Billings WD (1987) Constraints to plant growth, reproduction and establishment in arctic environments. Arct Alp Res 19:357-365

Billings WD, Mooney HA (1968) The ecology of arctic and alpine plants. Biol Rev 43:481-529

Bliss LC (1962) Adaptations of arctic and alpine plants to environmental conditions. Arctic 15:117-144

Bliss LC (1971) Arctic and alpine plant life cycles. Ann Rev Ecol Syst 2:405-438

Block W, Lewis-Smith RI, Kennedy AD (2009) Strategies of survival and resource exploitation in the Antarctic fellfield ecosystem. Biol Rev 84:449-484. doi:10.1111/j.1469-185X.2009.00084.x

Bonde EK (1965) Studies on the germination of seeds of Colorado alpine plants. Univ Colo Stud Ser Biol 14:1-16

Bouwmeester HJ, Karssen CM (1992) The dual role of temperature in the regulation of seasonal changes in dormancy and germination of seeds of Polygonum persicaria L. Oecologia 90:88-94

Brändel M, Jensen K (2005) Effect of temperature on dormancy and germination of Eupatorium cannabinum L. achenes. Seed Sci Res 15:143-151. doi:10.1079/SSR2005202

Brochmann C, Steen SW (1999) Sex and genes in the flora of Svalbard-implications for conservation biology and climate change. Det Norske Videnskaps-Akad I Mat Naturv Kl, Skr, Ny serie 38:33-72

Callaghan TV, Emanuelsson U (1985) Population structure and processes of tundra plants and vegetation. In: White $\mathbf{J}$ (ed) The population structure of vegetation. Dr W. Junk Publishers, Dordrecht, pp 399-439

Callaghan TV, Press MC, Lee JA, Robinson DL, Anderson CW (1999) Spatial and temporal variability in the responses of Arctic terrestrial ecosystems to environmental change. Polar Res 18:191-197. doi:10.1111/j.1751-8369.1999.tb00293.x

Campbell IB, Claridge GGC (1987) Antarctica: soils, weathering processes and environment. Developments in Soil Science 16. Elsevier Science Publishers, Amsterdam

Chapin FS (1983) Direct and indirect effect of temperature on arctic plants. Polar Biol 2:47-52

Convey P (2012) Polar terrestrial environments. In: Bell E (ed) Life at extremes: environments, organisms and strategies for survival. CABI, United Kingdom, pp 81-98

Cooper EJ, Alsos IG, Hagen D, Smith FN, Coulson SJ, Hodkinson ID (2004) Plant recruitment in the high arctic: seed bank and seedling emergence on Svalbard. J Veg Sci 15:115-224. doi:10. 1111/j.1654-1103.2004.tb02244.x
Corner RWM (1971) Studies in Colobanthus quitensis (Kunth) Bartl. and Deschampsia antarctica Desv. IV. Distribution and reproductive performance in the Argentine Islands. Br Antarct Surv Bull 26:41-50

Day TA, Ruhland CT, Grobe CW, Xiong F (1999) Growth and reproduction of Antarctic vascular plants in response to warming and UV radiation reductions in the field. Oecologia 119:24-35

Dionne J, Castonguay Y, Nadeau P, Desjardins Y (2001) Freezing tolerance and carbohydrate changes during cold acclimation of green-type annual bluegrass (Poа аппиа L.) ecotypes. Crop Sci 41:443-451. doi:10.2135/cropsci2001.412443x

Edwards JA (1974) Studies in Colobanthus quitensis (Kunth) Bartl. and Deschampsia antarctica Desv.: VI. Reproductive performance on Signy Island. Br Antarct Surv Bull 39:67-86

Ellis WM (1973) The breeding system and variation in populations of Poа аппиа L. Evolution 27:656-662

Ferron FA, Simões JC, Aquino FE, Setzer AW (2004) Air temperature time series for King George Island, Antarctica. Pesqui Antart Bras 4:155-169

Finch-Savage WE, Leubner-Metzger G (2006) Seed dormancy and the control of germination. New Phytol 171:501-523. doi:10. 1111/j.1469-8137.2006.01787.x

Førland EJ, Benestad R, Hanssen-Bauer I, Haugen JE, Skaugen TE (2011) Temperature and precipitation development at Svalbard 1900-2100. Adv Meteorol. doi:10.1155/2011/893790

Frenot Y, Gloaguen J-C (1994) Reproductive performance of native and alien colonizing phanerogams on a glacier foreland, Iles Kerguelen. Polar Biol 14:473-481

Gates DM (1980) Biophysical ecology. Springer, New York

Giełwanowska I, Bochenek A, Loro PM (2005) Biology of generative reproduction of Deschampsia antarctica. In: Frey L (ed) Biology of grasses. Polish Academy of Sciences, Kraków, pp 181-195

Hagen D (2002) Propagation of native Arctic and alpine species with a restoration potential. Polar Res 21:37-47. doi:10.1111/j.17518369.2002.tb00065.x

Holtom A, Greene SW (1967) The growth and reproduction of Antarctic flowering plants. Philos Trans R Soc Lond Ser B Biol Sci 252:323-337

Jónsdittór IS, Callaghan TV, Headley AD (1996) Resource dynamics within Arctic clonal plants. Ecol Bull 45:53-64

Kejna M (1999) Air temperature on King George Island, South Shetland Islands, Antarctica. Pol Polar Res 20:183-201

Kejna M, Araźny A, Sobota I (2013) Climatic change on King George Island in the years 1948-2011. Pol Polar Res 34:213-235. doi:10.2478/popore-2013-0004

Klimešová J, Doležal J, Prach K, Košnar J (2012) Clonal growth forms in arctic plants and their habitat preferences: a study from Petuniabukta, Spitsbergen. Pol Polar Res 33:421-442. doi:10. 2478/v10183-012-0019-y

Lewis Smith RI (1996) Introduced plants in Antarctica: potential impacts and conservation issues. Biol Conserv 76:135-146

Lewis-Smith RI (1994) Vascular plants as bioindicators of regional warming in Antarctica. Oecologia 99:322-328

Lush WM (1989) Adaptation and differentiation of golf course populations of annual bluegrass (Poa апnиa). Weed Sci 37:54-59

MacNamara EE (1973) Macro- and microclimate of the Antarctic coastal oasis, Molodezhnaya. Biul Peryglac 23:201-236

McGraw JB, Day TA (1997) Size and characteristics of a natural seed bank in Antarctica. Arct Alp Res 29:213-216

McGraw JB, Vavrek MC (1989) The role of buried viable seeds in arctic and alpine plant communities. In: Leck MA, Parker VT, Simpson RL (eds) Ecology of soil seed banks. Academic Press, New York, pp 91-105

Molina-Montenegro MA, Carrasco-Urra F, Rodrigo C, Convey P, Valladares F, Gianoli E (2012) Occurrence of the non-native 
annual bluegrass on the Antarctic mainland and its negative effects on native plants. Conserv Biol 26:717-723. doi:10.1111/ j.1523-1739.2012.01865.x

Müller E, Cooper EJ, Alsos IG (2011) Germinability of arctic plants is high in perceived optimal conditions but low in the field. Botany 89:337-348. doi:10.1139/B11-022

Olech M (1996) Human impact on terrestrial ecosystems in west Antarctica. Proc NIPR Symp Polar Biol 9:299-306

Parnikoza I, Kozeretska I, Kunakh V (2011) Vascular plants of the maritime Antarctic: origin and adaptation. Am J Plant Sci 2:381-395. doi:10.4236/ajps.2011.23044

Peck LS, Convey P, Barnes KA (2006) Environmental constraints on life histories in Antarctic ecosystems: tempos, timings and predictability. Biol Rev 81:75-109. doi:10.1017/ S1464793105006871

Pertierra LR, Lara F, Benayas J, Hughes KA (2013) Poa pratensis L., current status of the longest-established non-native vascular plant in the Antarctic. Polar Biol 36:1473-1481. doi:10.1007/ s00300-013-1367-8

Probert RJ (2000) The role of temperature in the regulation of seed dormancy and germination. In: Fenner $M$ (ed) Seeds. The ecology of regeneration in plants communities, 2nd edn. CABI, New York, pp 261-262

Ranal MA, De Santana DG (2006) How and why to measure the germination process? Rev Bras Bot 29:1-11

Robinson SA, Wasley J, Tobin AK (2008) Living on the edge-plants and global change in continental and maritime Antarctica. Glob Change Biol 9:1681-1717. doi:10.1046/j.1529-8817.2003. 00693.x

Ruhland CT, Day TA (2001) Size and longevity of seed banks in Antarctica and the influence of ultraviolet- $\mathrm{B}$ radiation on survivorship, growth and pigment concentrations of Colobanthus quitensis seedlings. Environ Exp Bot 45:143-154. doi:10.1016/ S0098-8472(00)00089-7

Savile DBO (1972) Arctic adaptations in plants. Monograph No 6. Canada Dept Agric Res Branch

Scherrer D, Körner C (2010) Infra-red thermometry of alpine landscapes challenges climatic warming projections. Glob Change Biol 16:2602-2613. doi:10.1111/j.1365-2486.2009. 02122.x

Soreng RJ (2007) Poa. In: Flora of North America Editorial Committee (ed) Flora of North America North of Mexico. Vol. 24 Magnoliophyta: Commelinidae (in part): Poaceae, part 1. Oxford University Press, New York, pp 486-602

Sørensen T (1941) Temperature relations and phenology of the northeast Greenland flowering plants. Medd Grønl 125:1-305

Vargas JM, Turgeon AJ (2004) Poa апnиа Physiology, culture and Control of annual bluegrass. Wiley, Hoboken

Warwick SI (1979) The biology of Canadian weeds. 37 Pоа апnиа L. Can J Plant Sci 59:1053-1066

Wódkiewicz M, Galera H, Chwedorzewska KJ, Giełwanowska I, Olech M (2013) Diaspores of the introduced species Pоа апnиа L. in soil samples from King George Island (South Shetlands, Antarctica). Arct Antarct Alp Res 45:1-5. doi:10.1657/19384246-45.3.415

Wódkiewicz M, Ziemiański M, Kwiecień K, Chwedorzewska KJ, Galera H (2014) Spatial structure of the soil seed bank of Poa аппиа L.- -alien species in the Antarctica. Biodivers Conserv 23:1339-1346. doi:10.1007/s10531-014-0668-8

Zinn KE, Tunc-Ozdemir M, Harper JF (2010) Temperature stress and plant sexual reproduction: uncovering the weakest links. J Exp Bot 61:1959-1968. doi:10.1093/jxb/erq053 